\title{
THE DELICATE BALANCE BETWEEN EDITOR AND AUTHOR
}

Through my first ten years as a teacher and scholar, one problem nagged at me. It is/was the question of community, the question of communication among scholars. As I began to write and have my writings published, I began to feel intensely, for the first time, the isolation of the scholarly vocation. Not the isolation of the lone author hunched over his typewriter. The isolation I speak of is felt only after the work is finished, and published (made public, given to a public). It is only then that it occurs to the writer to ask himself: for whom have I been writing? who is this public I wish to reach? and what will their response be, and how will they respond?

The truth is that usually we receive no response. Or, if there is response, it comes from unexpected quarters. I once had a letter from a schoolteacher in Spokane who had somehow stumbled across an article I had written which seemed to her to suggest that I was an ethical relativist, and stirred her to the heights of righteous indignation. And a Japanese editor of a folklore journal once wrote me that his typesetter, who knows very little English, nevertheless remarked: 'This man knows more about sacred festival drama than most Japanese.'

But these are exceptions, and exceptions follow the rule of whimsy, and are few and far between. For the most part, published scholarly effort is greeted with a solemn and yawning silence.

To make matters worse, the young scholar may encounter the stifled yawn and the polite attentiveness of his colleagues without benefit of the press. I once participated, over three years, in a faculty seminar in a provincial university, sponsored by one of the foundations of the day, and intended to foster an interest in non-Western studies (a phrase of the fifties, suggesting, in ethnocentric terms, our need to outgrow our ethnocentrism). One of us was a political scientist with an interest in boundary disputes, another an R.O.T.C. colonel with an interest in hydro-electric dams, and so on. When we turned our collective attention on the Middle East, Abernathy read a learned paper on border disputes during the Ottoman Empire, and we all listened politely; the following week Colonel Oxton reported on hydraulic engineering problems of the Aswan dam, and we all listened politely. My own paper on the whirling dervishes, I fear, meant as little to the Colonel as his paper on Aswan had meant to me. The following year it was Chinese border disputes, and Chinese water works, and then on to the Indian-Nepalese boundaries, and dams along the Krisna and Godaviri.

I came to feel, in retrospect, that the difficulty was not that my colleagues lacked talent, nor that their subjects were intrinsically 
dull, for they were not. The difficulty was that the idiom was wrong. Writing a detailed and footnoted treatise on a limited subject, without even hinting at the broader implications, and then reading from that paper, in a three or four-hour seminar, did not promote communication; it stymied it. We had assembled from all over the district, to compare notes and share our work as scholars, yet the very format served only to promote our isolation from one another.

It is, alas, the same with our academic journals. I had not fully appreciated that fact until some five years ago, when I left a university which I had served for fifteen years, to move on to greener pastures. I had subscribed, over those years, to a half-dozen or so scholarly journals, and my office shelves were stacked high with the accumulation. It was too much to move, moving costs being what they are, and I started to weed out my collection. I went through them issue by issue, and if there was nothing really worth keeping in a single issue, I dropped it into the waste basket. To my delight, two journals, one dealing with Islamic studies and the other with Buddhism-and neither connected with a learned society-proved worthy of preservation in toto. But the better known, standard journals in my field did not hold up as well. I kept just a handful from one, and a half-dozen of another. And when I had done with the quarterly I read (religiously) for the full fifteen years, not a single issue escaped the waste basket, until I came to the last. That was an index to the past twenty-five years of the journal. I thought I might just keep that, and consult the library for the missing periodical, if ever the need arose. It never has, and I suppose on my next move I'll throw away the index too.

Again, the problem is not that the American scholar is not scholar enough. It is that he is not writer enough. And his scholarship suffers as a consequence. He needs to be reminded that he is in some sense an essayist, communicating his ideas and his discoveries and his worries by means of a literary form that looks easy, but is exceedingly difficult to master, calling for great patience and unusual discipline in the selection and weighing of phrases and words. He needs to be reminded that as an essayist, he stands in the company of men like Waldo Emerson and George Orwell, Aldous Huxley and W. H. Hudson, whose finest efforts went, not into their potboilers, but into their essays.

He needs also to be reminded that profundity often lies in simplicity, rather than complexity. I once returned from a field trip in Burma, laden with diagrams of monasteries and meditation centers, interviews with monks and laymen, detailed slides of pagodas and uposatha gatherings, and all such data a scholar feels he needs to make his point. In talks here and there, I found myself 
trying to communicate something of the mood in those monasteries, something of the flavor of Theravada Buddhism. Then one evening some students invited me over for an informal talk on my Burma trip. Tired of carrying my academic baggage, I scribbled some haiku-like poems on the back of an envelope, and read them off, interspersing poems with commentary, in the fashion of a travel diary (what the Japanese call haibun). I had thought my important observations were in my data, and the poems would contain only impressions of the unimportant, but soon realized that the reverse was true. The simpler the form, the more concise the image, the larger the idea contained within.

Lastly, the writer needs to be reassured that it is all right to be playful. That is a bit of wisdom I learned from the editor of a long-established journal of psychology. The heavily documented, solemnly turned-out article that is crammed with self-importance and written with a firm hand is easy to come by. But an essay that is light and inventive and truly experimental is quite rare. Playful scholarship is reflected in the style, but it goes beyond style. The playful scholar has a playful spirit.

The editor's task is no less demanding, for he must know how to recognize style, and then to go beyond style, and recognize substance. He needs exceptional breadth and versatility. He needs to know the present boundaries of a dozen fields of scholarship, and he needs a sixth sense to tell him where the next breakthroughs may come. He needs to be flexible, open to the new and the experimental, ready for the unexpected, but short-tempered with the trendy. And most important of all, he must know how to show respect for his authors. We all know editors with a fetishist's attachment to their blue pencils. They delete a word here and there and substitute their own, in sentence after sentence, disrupting the whole rhythm, the whole music of the piece, so that in the end it is neither theirs nor the author's. No one who takes pride in his work will make the mistake of submitting it twice to that sort of editor. On the other hand, I have known editors who can cut a book review in half, and then hear from its author that he hadn't remembered how good (or how short) his review was! The trick, of course, is in knowing which half to eliminate. A good editor knows when to slash, and when not; but he always leaves the author's style, his own special music, intact. A bad editor has no perspective, no vision; and so he can only pick at nits.

But these are all the problems of the past, I am told. A new era is dawning, the era of the photocopied journal. The editor is a mere impressario, a benign and smiling clerk who promises to accept every single manuscript submitted to him, a scholarly St. Peter who is now 
allowed, thanks to the miracles of technology, to admit everyone to his paradise. The "subscriber" to his journal simply receives a monthly or quarterly listing of manuscripts received. He checks off the ones he would like to receive, and returns the list. Our editor-clerk then runs the desired articles through his basement duplicator, and sends them off to the "subscriber," who need pay only for the articles he requests. It is the American dream. All ill feelings, all contention have been eliminated. It is the Forest Lawn of scholarly writing. And I for one shall not subscribe. I would rather take my chances, even with that editor in Kentucky with the stubby blue pencil. Writers and editors are as necessary to each other as a husband and wife are to a marriage. And a well-written and well-edited journal lies at the very center of the community of scholars, when and where scholars achieve community.

- ALBERT WILLIAM SADLER

\section{HORIZONS AND BIBLICAL STUDIES}

The College Theology Society has begun Horizons because of a need for a journal that will do what others have not done. It promises to present substantive articles in a form that is intelligible to non-specialists.

Many journals have begun with this purpose in mind, but few have been successful. It is not easy to walk the thin line between what is solid material and what is simply popular or to connect "scholarly" with "for the non-specialist." But the members of the Society are to be credited for their willingness to try, and hopefully the editors will be faithful to the charge.

It is especially important that this venture succeed. The reason is that the non-specialists are not persons outside our membership and discipline; rather, they are any colleague with a specialty other than one's own. Theology is not what it useed to be; it has broadened and reached out to include many specialties. In fact it has broadened so much that many departments prefer the more expansive title of "religious studies," and many outsiders question whether it is still a discipline.

There is no group who will welcome this attempt more than those who make the Bible their study. They have experienced a growing sense of loneliness and isolation as theologians moved toward (and into) the social sciences, philosophy and the Far East. Certainly, Bible courses are still included in the college curriculum, 